\title{
Vascular Ehlers-Danlos syndrome - case report
}

\author{
Ana Marija Slišković, \\ ๑Ana Šutalo, \\ - Sanda Huljev Frković, \\ (1)Andrea Crkvenac \\ Gregorek, \\ 니jijana Banfić, \\ -Majda Vrkić \\ Kirhmajer $^{*}$
}

University of Zagreb School of Medicine, University Hospital Centre Zagreb, Zagreb, Croatia

RECEIVED:

November 25, 2020

ACCEPTED:

December 18, 2020

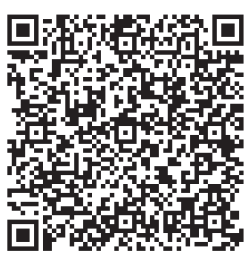

$\square$ Cardiologia Croatica 2021;16(1-2):74.
KEYWORDS: Ehlers-Danlos syndrome, celiprolol, collagen

CITATION: Cardiol Croat. 2021;16(1-2):74. | https://doi.org/10.15836/ccar2021.74

*ADDRESS FOR CORRESPONDENCE: Majda Vrkić Kirhmajer, Klinički bolnički centar Zagreb, Kišpatićeva 12, HR10000 Zagreb, Croatia. / Phone: +385-91-5273592 / E-mail: majda_vrkic@yahoo.com

ORCID: Ana Marija Slišković, https://orcid.org/0000-0001-6622-7572 • Ana Šutalo, https://orcid.org/0000-0002-7644-6362 Sanda Huljev Frković, https://orcid.org/0000-0003-1513-2965 • Andrea Crkvenac Gregorek, https://orcid.org/0000-0002-7790-1347 Ljiljana Banfić, https://orcid.org/0000-0002-4538-8980 • Majda Vrkić Kirhmajer, https://orcid.org/0000-0002-1340-1917

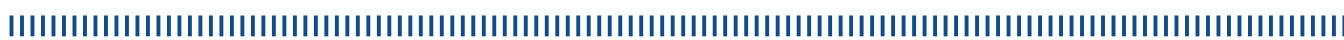

Introduction: Vascular Ehlers-Danlos syndrome (VEDS) is considered the most severe form of EDS because of its typical life-threatening complications in young adults: spontaneous rupture of arteries, uterus or intestine ${ }^{1}$. The prevalence of vEDS is at least 1:200.000. It is associated with autosomal dominant mutation in COL3Al gene, which encodes pro-alpha 1 chains of type III collagen. The median life expectancy is 48 to 51 years. The beneficial role of celiprolol in reduction of arterial complications has been described, and the mechanisms may be related to reduction of hemodynamic stress and by upregulation of collagen synthesis via transforming growth factor- $\beta^{2,3}$

Case report: A 26 -year-old man was referred with long history of serious vascular complication. From early childhood he was prone to spontaneous bruising. At the age of 7 , after minor trauma, he had a duodenal hematoma. Hemophilia was ruled out. In 2014, urgent nephrectomy was done because of spontaneous rupture of right renal artery. Calf varicose veins were treated with foam sclerotherapy in 2016. In 2017, urgent femoro-femoral bypass was performed due to spontaneous rupture of the left common iliac artery (CIA) and failure to repair extremely vulnerable CIA wall. Several months later hybrid vascular procedure was done due to spontaneous dissection of right external iliac artery. Early postoperative course was complicated by spontaneous pneumothorax. His physical appearance was also suggestive to vEDS: thin skin, characteristic facial appearance (thin lips, small chin, thin nose, prominent eyes with dark circles), small joints hypermobility. Molecular genetic testing in 2019 confirmed vEDS: our patient is heterozygous for COL3A1c.1149+2_1149+51del. His current medical therapy includes vitamin $\mathrm{C}$ and tolerable dose of celiprolol. For the last three years he is without new adverse vascular events.

Conclusion: Accurate diagnosis, genetic consulting, avoiding high risk activities and procedures are crucial in patients with vEDS. Endovascular or surgical intervention are mainly reserved for urgent complications of arterial or organ rupture. Celiprolol, a beta blocker with a unique pharmacologic profile, demonstrated a promising role in reduction of vascular complication in vEDS.
LITERATURE IIIIIIIIIIIIIIIIIIIIIIIIIIIIIIIIIIIIIIIIIIIIIIIIIIIIIIIIIIIIIIIIIIIIIIIIIIIIIIIIIIIIIIIIIIIIIIIIII

1. Pepin M, Schwarze U, Superti-Furga A, Byers PH. Clinical and genetic features of Ehlers-Danlos syndrome type IV, the vascular type. N Engl J Med. 2000 Mar 9;342(10):673-80. https://doi.org/10.1056/NEJM200003093421001

2. Ong KT, Perdu J, De Backer J, Bozec E, Collignon P, Emmerich J, et al. Effect of celiprolol on prevention of cardiovascular events in vascular Ehlers-Danlos syndrome: a prospective randomised, open, blinded-endpoints trial. Lancet. 2010 0ct 30;376(9751):1476-84. https://doi.org/10.1016/s0140-6736(10)60960-9

3. Frank M, Adham S, Seigle S, Legrand A, Mirault T, Henneton P, et al. Vascular Ehlers-Danlos Syndrome: Long-Term Observational Study. J Am Coll Cardiol. 2019 Apr 23:73(15):1948-1957. https://doi.org/10.1016/j.jacc.2019.01.058 